\title{
CONTAMINATION OF BONE ALLOGRAFTS
}

\author{
ANALYSIS OF INCIDENCE AND PREDISPOSING FACTORS
}

R. L. M. DEIJKERS, R. M. BLOEM, P. L. C. PETIT, R. BRAND, S. B. W. VEHMEYER, M. R. VEEN

From the University Hospital, Leiden and the BIS Foundation, Leiden, The Netherlands

We analysed the bacterial contamination of 1999 bone allografts retrieved from 200 cadaver donors under sterile operating conditions. The effect of various factors on the relative risk of contamination was estimated using a multiple logistic regression model.

Organisms of low pathogenicity were cultured from $50 \%$ of the grafts and of high pathogenicity from $3 \%$. The risk of contamination with low pathogenic organisms (mainly skin commensals) increased by a factor of 1.6 for each member added to the procurement team. The risk of contamination with high pathogenic organisms (mainly contaminants from the gastrointestinal tract) was 3.4 times higher in donors with a traumatic cause of death and 5.2 times higher in those with a positive blood culture. Preceding organ procurement did not significantly influence the risk of contamination. Rinsing the graft with an antibiotic solution was not an effective decontamination method.

The major source of contamination is exogenous and is strongly influenced by the procurement team. Contamination from endogenous sources can be controlled by donor selection. We discuss methods that can be used to decrease contamination and the rate of discarding of bone allografts.

J Bone Joint Surg [Br] 1997;79-B:161-6.

Received 5 August 1996; Accepted after revision 20 September 1996

R. L. M. Deijkers, MD, Orthopaedic Registrar

R. M. Bloem, MD, PhD, Consultant Orthopaedic Surgeon and Medical Director, Leiden Bone Bank

M. R. Veen, MD, PhD, Orthopaedic Registrar

P. L. C. Petit, MD, Consultant, Department of Microbiology

R. Brand, PhD, Consultant, Department of Medical Statistics

University Hospital Leiden, Rijnsburgerweg 10, 2300 RC Leiden, The Netherlands.

S. B. W. Vehmeyer, MD, Staff Physician

BIS Foundation / Leiden Bone Bank, Plesmanlaan 100, $2301 \mathrm{CH}$ Leiden, The Netherlands.

Correspondence should be sent to Dr R. L. M. Deijkers.

C1997 British Editorial Society of Bone and Joint Surgery 0301-620X/97/17137\$2.00
There is always a risk of bacterial contamination when harvesting bone allografts. ${ }^{1-5}$ Grafts may be contaminated during the process of procurement from the surgeon or the donor. The risk of infecting the recipient can be reduced by adequate microbiological monitoring. If contamination is detected the choices are additional sterilisation or discarding of the allograft. Sterilisation can alter the biomechanical and biological properties. ${ }^{6-8}$ For osteochondral grafts, it is unsuitable as it kills cartilage cells. Such grafts should be preserved fresh frozen without additional sterilisation. To prevent the wastage of time and grafts, contamination should be minimised.

The aim of our study was to determine the incidence and potential causes of contamination and to assess the effectiveness of antibiotic rinsing of allografts.

\section{MATERIAL AND METHODS}

Potential cadaver donors were carefully selected and screened according to the guidelines of the American Association of Tissue Banks (AATB) ${ }^{9}$ and the European Association of Musculo-Skeletal Transplantation (EAMST). ${ }^{10}$ They were not considered for tissue donation if there was a clinical history of sepsis at the time of death. The methods of procurement were those described by Tomford. ${ }^{1,11}$ Using aseptic techniques bone and soft-tissues were procured in an operating theatre within 24 hours of death. Blood from the heart or subclavian vein was taken for culture before the procurement.

After removal the grafts were rinsed with an antibiotic solution (bacitracin $50000 \mathrm{U} / \mathrm{L}$, Apothekernes Lab, Oslo, and polymyxin-B 500000 U/L, Pfizer, Connecticut, USA). Allografts from the last 50 donors were rinsed with sterile saline only. Subsequently, swabs were taken of the entire graft surface, and if possible the medullary canal, using a $15 \mathrm{~cm}$ polyester-tipped applicator (Becton Dickinson and Company, Cockeysville, Maryland) and placed in a transport medium (Port-A-Cul, Becton Dickinson). They were then inoculated on to blood agar and chocolate agar plates and cultured under aerobic and anaerobic conditions. The entire swabstick was placed in a brain heart infusion (BHI) broth (Oxoid; Unipathe, Basingstoke, UK). After two to five days, the broth was subcultured on agar plates which were cultured aerobically and anaerobically for 72 hours. Blood samples were cultured aerobically and anaerobically 
for seven days. The level of contamination (microbial load) was considered low if micro-organisms grew only in the broth and high when they grew directly on the plates.

Between December 1988 and June 1994 we procured bone grafts from 200 cadaver donors. The cause of death was cardiac failure in 87 , cerebral haemorrhage in 50 , trauma in 42 and other causes in 21 . The mean duration between death and procurement of tissue was 8.2 hours (1.0 to 23.8). The bone and soft-tissue procurements were preceded by an organ procurement in 58 and by a heart-valve procurement in 42 cases. The number of staff members performing the procurement varied from three to six (mean 4.6). The mean duration of the procurement process was 1.7 hours ( 0.75 to 3.0 ).

A total of 1999 separate bone and related soft-tissue grafts was obtained with each cadaver contributing six to eighteen. These were; humerus 192, radius 24, ilium/hemipelvis 141 , femoral fragments 655 , tibial fragments 399 , Achilles tendon 238, fascia lata 48, others 19.

Statistical analysis. We performed a multivariate analysis, using a logistic regression model. As one donor produced several bone grafts, the correlations between grafts within one donor was accounted for using a random-effects model. We used the package EGRET. ${ }^{12}$ We considered $\mathrm{p}<0.05$ as significant. The effect of various factors on the relative risk of contamination was estimated by odds ratios; $p$ values were calculated on the basis of the likelihood ratio tests.

\section{RESULTS}

Graft contamination. From the 1999 allografts procured, micro-organisms of low pathogenicity were cultured from $999(50 \%)$ and micro-organisms of high pathogenicity from 57 (3\%) (Table I). From 943 grafts (47\%) no organisms were cultured. Contamination with organisms of low pathogenicity was of low microbial load in 69\% (689/999) of the cases.

For any one donor, the proportion of grafts which were contaminated with micro-organisms of low pathogenicity varied from $0 \%$ to $100 \%$ and with micro-organisms of high pathogenicity primarily from $0 \%$ to $30 \%$ (Fig. 1).

A single organism was cultured from 942 grafts and more than one from 114. The most frequently cultured organisms was coagulase-negative staphylococcus $(82 \%)$. Of organisms of high pathogenicity the most frequently seen were Streptococcus species (Table I).

Blood contamination. Blood for culture was obtained from 186 of the 200 donors. Seventeen cultures contained organisms of low pathogenicity originating from the skin but identical organisms were not cultured from their allografts. We considered these cultures to be falsely positive because of external contamination due to needle perforation. Twenty-six blood cultures were truly positive. The predominant organisms cultured were Streptococcus species.

Predisposing factors for graft contamination. Multiple logistic regression analysis showed that several risk factors were simultaneously significant. Furthermore, the correla- tion of grafts within one donor (random effect) was highly significant $(\mathrm{p}<0.001)$. To account for this correlation when assessing the significance of the risk factors, a random effect term was added to the logistic regression model. If this correlation is not taken into account unwarranted levels of significance may arise. For the analysis a distinction was made between micro-organisms of high pathogenicity and those of low pathogenicity.

Micro-organisms of low pathogenicity. The number of staff members performing the procurement, the type of graft and the time since death were risk factors associated with con-

Table I. Details of micro-organisms cultured from bone grafts

\begin{tabular}{lc}
\hline Micro-organisms & $\begin{array}{c}\text { Number of } \\
\text { times cultured* }\end{array}$ \\
\hline Low pathogenicity & \\
Coagulase-negative staphylococcus & 959 \\
Corynebacterium species & 97 \\
Propionobacterium acnes & 29 \\
Bacillus species & 15 \\
Diphtheroids & 4 \\
Micrococcus & 2 \\
Sarcina & 3 \\
High pathogenicity & \\
Streptococcus species & 36 \\
Staphylococcus aureus & 9 \\
Clostridium species & 5 \\
Bacteroides & 4 \\
Escherichia coli & 4 \\
Yeast & 3 \\
Pseudomonas aeruginosa & 1 \\
Candida & 1 \\
Grafts connected with & \\
Micro-organisms of low pathogenicity & $999(50 \%)$ \\
Micro-organisms of high pathogenicity & $57(3 \%)$ \\
No growth & $943(47 \%)$ \\
Total cultures & 1999 \\
\hline &
\end{tabular}

* multiple organisms were cultured from 114 grafts

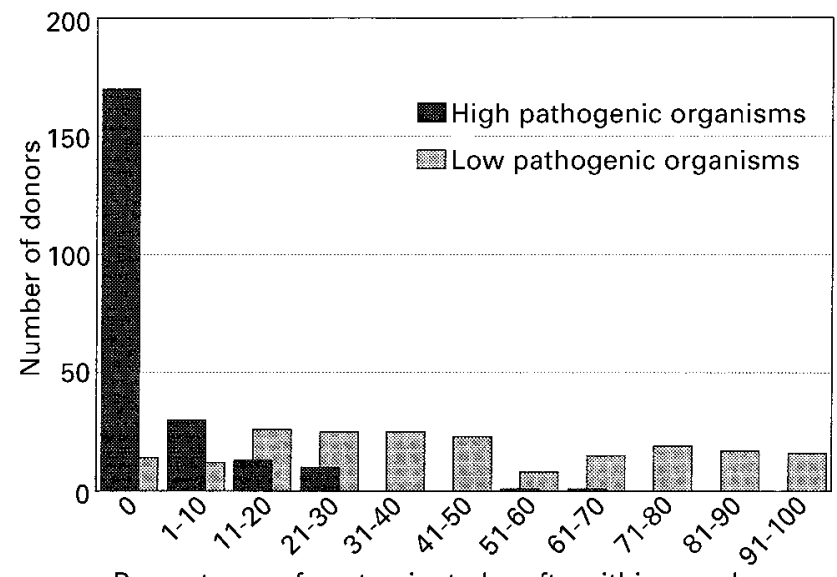

Percentages of contaminated grafts within one donor

Fig. 1

Frequency histogram for percentages of contaminated grafts within one donor. Grafts can be contaminated with organism of high and low pathogenicity. 
Table II. The effect of various factors on the relative risk of graft contamination with low pathogenic organisms (see Table I) estimated by odds ratios

\begin{tabular}{|c|c|c|c|c|c|}
\hline \multirow[b]{2}{*}{ Factors } & \multicolumn{2}{|c|}{$\begin{array}{l}\text { Contamination } \\
\text { of grafts* }\end{array}$} & \multicolumn{3}{|c|}{ Logistic regression $\dagger$} \\
\hline & No & Yes & Odds ratio & $95 \% \mathrm{CI}$ & p value \\
\hline $\begin{array}{l}\text { Traumatic cause of death } \\
\text { No }(\mathrm{n}=158) \\
\text { Yes }(\mathrm{n}=42)\end{array}$ & $\begin{array}{l}767 \\
176\end{array}$ & $\begin{array}{l}802 \\
197\end{array}$ & $\begin{array}{l}(1) \\
1.3\end{array}$ & 0.7 to 2.2 & 0.39 \\
\hline $\begin{array}{l}\text { Preceding procedure } \\
\text { No }(\mathrm{n}=100) \\
\text { Organ }(\mathrm{n}=58) \\
\text { Heart valve }(\mathrm{n}=42)\end{array}$ & $\begin{array}{l}490 \\
263 \\
190\end{array}$ & $\begin{array}{l}461 \\
326 \\
212\end{array}$ & $\begin{array}{l}(1) \\
0.9 \\
1.5\end{array}$ & $\begin{array}{l}0.5 \text { to } 1.5 \\
0.9 \text { to } 3.1\end{array}$ & 0.27 \\
\hline $\begin{array}{l}\text { Time since death } \\
\text { Per } 1 \mathrm{hr} \text { increase }\end{array}$ & & & 0.93 & 0.9 to 1.0 & 0.002 \\
\hline $\begin{array}{l}\text { Team members } \\
\begin{array}{c}3(\mathrm{n}=5) \\
4(\mathrm{n}=90) \\
5(\mathrm{n}=90) \\
6(\mathrm{n}=15)\end{array}\end{array}$ & $\begin{array}{l}34 \\
456 \\
387 \\
66\end{array}$ & $\begin{array}{l}13 \\
391 \\
483 \\
112\end{array}$ & $\begin{array}{l}(1) \\
1.6 \\
2.4 \\
3.7\end{array}$ & 1.2 to 2.5 & 0.001 \\
\hline $\begin{array}{l}\text { Procurement duration } \\
\text { Per } 1 \mathrm{hr} \text { increase }\end{array}$ & & & 1.3 & 0.7 to 2.5 & 0.42 \\
\hline $\begin{array}{l}\text { Type of graft } \\
\text { Humerus } \\
\text { Radius } \\
\text { Femur } \\
\text { Tibia } \\
\text { Fibula } \\
\text { Pelvis } \\
\text { Achilles tendon }\end{array}$ & $\begin{array}{l}84 \\
18 \\
320 \\
190 \\
150 \\
65 \\
87\end{array}$ & $\begin{array}{l}97 \\
6 \\
313 \\
204 \\
126 \\
73 \\
145\end{array}$ & $\begin{array}{l}(1) \\
0.4 \\
0.9 \\
1.0 \\
0.8 \\
1.1 \\
1.6\end{array}$ & $\begin{array}{l}0.1 \text { to } 1.2 \\
0.6 \text { to } 1.4 \\
0.6 \text { to } 1.6 \\
0.5 \text { to } 1.2 \\
0.6 \text { to } 2.0 \\
1.3 \text { to } 3.4\end{array}$ & $\begin{array}{l}0.004 \\
0.29 \\
0.81 \\
0.68 \\
0.36 \\
0.30 \\
0.004\end{array}$ \\
\hline $\begin{array}{l}\text { Blood contamination } \neq \\
\text { No }(n=160) \\
\text { Yes }(n=26)\end{array}$ & $\begin{array}{l}755 \\
121\end{array}$ & $\begin{array}{l}814 \\
112\end{array}$ & $\begin{array}{l}(1) \\
0.9\end{array}$ & 0.6 to 1.6 & 0.85 \\
\hline $\begin{array}{l}\text { Antibiotic rinse } \\
\text { No }(n=50) \\
\text { Yes }(n=150)\end{array}$ & $\begin{array}{l}191 \\
752\end{array}$ & $\begin{array}{l}260 \\
739\end{array}$ & $\begin{array}{l}(1) \\
0.5\end{array}$ & 0.2 to 0.8 & 0.02 \\
\hline
\end{tabular}

* 57 of 1999 grafts were contaminated with high pathogenic organisms; these were not included in this analysis

$\dagger$ with random-effect to account for graft-within-donor structure; all estimated effects

(expressed by the odds ratios) are adjusted for each other in a multivariate analysis

$\$$ blood sampling not performed for 14 donors; $=140$ grafts

tamination (Table II). Each staff member added to the procurement team increased the risk of contamination by a factor of $1.6(p=0.001)$. For each hour increase between the time of death and procurement, the risk of contamination decreased by a factor of $0.93(\mathrm{p}=0.002)$. The type of graft also influenced the risk of contamination $(p=0.004)$. The contamination rate was low for the radii and high for the Achilles tendons. Trauma as the cause of death, preceding organ/heart-valve procurement and bone procurement duration were not associated with increased risk of contamination with organisms of low pathogenicity (Table II).

Micro-organisms of high pathogenicity. Two factors were associated with an increased risk of contamination with organisms of high pathogenicity (Table III). A traumatic cause of death increased the risk by a factor of 3.4 $(\mathrm{p}=0.007)$ and a positive blood culture by a factor of 5.2 $(p=0.005)$. In nine out of 26 donors with a positive blood culture, identical organisms were found in one or more cultures taken from the grafts.

Predisposing factors for blood contamination. A trau- matic cause of death increased the risk of blood contamination by a factor of $14.6(\mathrm{p}<0.001)$. Time from death and preceding organ/heart-valve procurement did not alter the risk of blood contamination (Table IV).

Effectiveness of antibiotic rinse. All the allografts procured from the first 150 donors (1544 grafts) were rinsed with an antibiotic solution, but in the last 50 donors (455 grafts) only saline was used. Multiple logistic regression analysis of the data showed that rinsing with an antibiotic solution decreased the risk of contamination with organisms of low pathogenicity by a factor of $0.5(p=0.02)$ (Table II). Further analysis showed that this decrease was caused by a reduction in the number of grafts with a low microbial load ( $31 \% v 45 \%)$, but the risk of contamination with organisms of high pathogenicity did not alter (Table III).

\section{DISCUSSION}

Despite careful donor selection and aseptic tissue procurement, we frequently cultured micro-organisms from bone 
Table III. The effect of various factors on the relative risk of graft contamination with high pathogenic organisms (see Table I) estimated by odds ratios

\begin{tabular}{|c|c|c|c|c|c|}
\hline \multirow[b]{2}{*}{ Factors } & \multicolumn{2}{|c|}{$\begin{array}{l}\text { Contamination } \\
\text { of grafts* }\end{array}$} & \multicolumn{3}{|c|}{ Logistic regression $\dagger$} \\
\hline & No & Yes & Odds ratio & $95 \% \mathrm{CI}$ & p value \\
\hline $\begin{array}{l}\text { Traumatic cause of death } \\
\text { No }(n=42) \\
\text { Yes }(n=158)\end{array}$ & $\begin{array}{l}1569 \\
373\end{array}$ & $\begin{array}{l}31 \\
26\end{array}$ & $\begin{array}{l}(1) \\
3.4\end{array}$ & 2.0 to 5.5 & 0.007 \\
\hline $\begin{array}{l}\text { Preceding procedure } \\
\text { No }(\mathrm{n}=100) \\
\text { Organ }(\mathrm{n}=58) \\
\text { Heart valve }(\mathrm{n}=42)\end{array}$ & $\begin{array}{l}951 \\
589 \\
402\end{array}$ & $\begin{array}{l}26 \\
22 \\
9\end{array}$ & $\begin{array}{l}(1) \\
1.0 \\
0.9\end{array}$ & $\begin{array}{l}0.4 \text { to } 3.0 \\
0.3 \text { to } 3.5\end{array}$ & 0.76 \\
\hline $\begin{array}{l}\text { Time since death } \\
\text { per } 1 \mathrm{hr} \text { increase }\end{array}$ & & & 1.0 & 0.9 to 1.2 & 0.86 \\
\hline $\begin{array}{l}\text { Team members } \\
3(\mathrm{n}=5) \\
4(\mathrm{n}=90) \\
5(\mathrm{n}=90) \\
6(\mathrm{n}=15)\end{array}$ & $\begin{array}{l}47 \\
847 \\
870 \\
178\end{array}$ & $\begin{array}{l}0 \\
23 \\
28 \\
6\end{array}$ & $\begin{array}{l}(1) \\
1.0 \\
1.0 \\
1.0\end{array}$ & 0.5 to 1.9 & 0.93 \\
\hline $\begin{array}{l}\text { Procurement duration } \\
\text { Per } 1 \mathrm{hr} \text { increase }\end{array}$ & & & 1.3 & 0.4 to 4.3 & 0.65 \\
\hline $\begin{array}{l}\text { Type of graft } \dagger \\
\text { Humerus } \\
\text { Radius } \\
\text { Femur } \\
\text { Tibia } \\
\text { Fibula } \\
\text { Pelvis } \\
\text { Achilles tendon }\end{array}$ & $\begin{array}{l}181 \\
24 \\
633 \\
394 \\
276 \\
138 \\
323\end{array}$ & $\begin{array}{l}11 \\
0 \\
22 \\
5 \\
7 \\
3 \\
6\end{array}$ & $\begin{array}{l}- \\
- \\
- \\
- \\
- \\
- \\
-\end{array}$ & & - \\
\hline $\begin{array}{l}\text { Blood contamination } \neq \\
\text { No }(\mathrm{n}=160) \\
\text { Yes }(\mathrm{n}=26)\end{array}$ & $\begin{array}{l}1593 \\
233\end{array}$ & $\begin{array}{l}9 \\
24\end{array}$ & $\begin{array}{l}(1) \\
5.2\end{array}$ & 1.6 to 17 & 0.005 \\
\hline $\begin{array}{l}\text { Antibiotic rinse } \\
\text { No }(\mathrm{n}=50) \\
\text { Yes }(\mathrm{n}=150)\end{array}$ & $\begin{array}{l}411 \\
1491\end{array}$ & $\begin{array}{l}4 \\
53\end{array}$ & $\begin{array}{l}(1) \\
1.9\end{array}$ & 0.5 to 11 & 0.30 \\
\hline
\end{tabular}

* with random-effect to account for graft-within-donor structure; all estimated effects (expressed by the odds ratios) are adjusted for each other in a multivariate analysis $\dagger$ logistic regression on 'type of graft' was invalid because of small size of the (sub-) populations

$\$$ blood sampling not performed for 14 donors; $=140$ grafts

Table IV. The effect of various factors on the relative risk of blood contamination estimated by odds ratios

\begin{tabular}{|c|c|c|c|c|c|}
\hline \multirow[b]{2}{*}{ Factors } & \multicolumn{2}{|c|}{$\begin{array}{l}\text { Contamination } \\
\text { of grafts* }\end{array}$} & \multicolumn{3}{|c|}{ Logistic regression $\dagger$} \\
\hline & No & Yes & Odds ratio & $95 \% \mathrm{CI}$ & p value \\
\hline Traumatic cause of death & & & & & $<0.001$ \\
\hline No $(n=147)$ & 137 & 10 & (1) & & \\
\hline Yes $(n=39)$ & 23 & 16 & 14.6 & 5.1 to 43 & \\
\hline Preceding procedure & & & & & 0.42 \\
\hline No $(\mathrm{n}=98)$ & 83 & 15 & (1) & & \\
\hline Organ $(n=50)$ & 46 & 4 & 0.4 & 0.1 to 1.5 & \\
\hline Heart valve $(n=38)$ & 31 & 7 & 0.6 & 0.2 to 2.2 & \\
\hline Postmortem time $\ddagger$ & & & & & 0.08 \\
\hline Per $1 \mathrm{hr}$ increase & & & 1.2 & 1.0 to 1.5 & \\
\hline
\end{tabular}

* a total of 186 blood cultures were analysed; in 14 out of 200 donors blood samples were not obtained due to technical reasons

$\dagger$ with random-effect to account for graft-within-donor structure; all estimated effects (expressed by the odds ratio) are adjusted for each other in a multivariate analysis $\ddagger$ if there was a preceding procedure; the samples were taken at the time of the preceding procurement. To exclude bias, we only analysed procurement without preceding organ/heart-valve procurement 
and soft-tissue allografts. Those of low pathogenicity, which we considered to be skin commensals, were cultured from $50 \%$ of the grafts. Two-thirds of these grafts $(69 \%)$ had what we termed low microbial load. Micro-organisms of high pathogenicity were cultured from only $3 \%$ of the allografts. Others have reported rates of bacterial contamination between $5 \%$ and $44 \% .^{1-5}$ Comparison of the contamination rates in these reports is not possible because of differences in culture techniques or lack of information about the technique used. Blood cultures from $14 \%$ of the allograft donors were positive, Streptococcus species being most frequently grown. This agrees with another report ${ }^{13}$ in which a comparable percentage of blood was contaminated with organisms other than skin commensals.

We are of the opinion that it is important to distinguish between allograft contamination with micro-organisms of low and high pathogenicity, as they are likely to originate from different sources. Most organisms of low pathogenicity are skin commensals (e.g. coagulase-negative staphylococci, Corynebacterium species and Propionibacterium acnes) and probably represent external contamination at the time of procurement. Organisms of high pathogenicity probably originate from endogenous sources in the donor. They are usually contaminants from the upper respiratory or gastrointestinal tract (e.g. streptococci, Staphylococcus aureus and Escherichia coli) and are more likely to cause infection in the recipient of the allograft.

For each staff member added to the procurement team the risk of contamination with organisms of low pathogenicity increased by a factor of 1.6. Micro-organisms shed from the skin of the staff are considered the major source of airborne bacteria, and are deposited by gravity on to the surface of the grafts. ${ }^{14}$ In conventionally ventilated operating rooms around $95 \%$ of the wound bacteria come from the air. ${ }^{15,16}$ We recommend that allograft procurement should be performed by a small and experienced surgical team.

The procurement of Achilles tendons was associated with an increased risk of contamination with skin commensals. Adhesive drapes used at this site were frequently found to detach. As the tendons were the last to be removed there was a greater risk of their contact with heavily contaminated surgical drapes or instruments.

We found it interesting that preceding procurement of organs or heart valves did not influence the risk of contamination with low pathogenic organisms. We suggest two explanations. First, micro-organisms shed from the different staff performing the preceding procurement are a relatively small risk for contamination, already having settled to the floor and other surfaces. Particles settle (move downwards) at a speed of 20 to $30 \mathrm{~cm} / \mathrm{min} .{ }^{14}$ Once settled on the floor or another surface, organisms are only resuspended into the air with great difficulty. ${ }^{17}$ Secondly, during donor and back table preparation, the number of organisms is increased substantially. Our measurement of colonyforming units (CFU) in the operating theatre showed a mean count of $5 \mathrm{CFU} / \mathrm{m}^{3}$ (0 to 16 ) in an empty operating theatre just before the procurement with a sharp rise to $65 \mathrm{CFU} / \mathrm{m}^{3}$ (8 to 235 ) during donor and backtable preparation. This was independent of any preceding procurement. By the time the surgical excision of the allografts occurred the number had dropped to $25 \mathrm{CFU} / \mathrm{m}^{3}$ (0 to 125 ).

Contamination with organisms of high pathogenicity can be reduced by careful donor selection. If there had been trauma to the maxillofacial area or abdomen bacteraemia is likely to occur with haematogenous spread to the bones. We found that after a traumatic cause of death the risk of graft contamination with organisms of high pathogenicity increased by a factor of $3.4(\mathrm{p}=0.007)$, and the risk of blood contamination by a factor of 14.6 ( $\mathrm{p}<0.001)$. Haematogenous spread was emphasised by the strong relationship between a positive blood culture and the contamination of bone with high pathogenic organisms (odds ratio $=5.2$, $\mathrm{p}=0.005$ ). Thus, caution must be exercised before selecting as allograft donors those who have had severe trauma.

It has been reported that transmigration of micro-organisms from their areas of colonisation to new sites is not frequent after death if tissues are excised within a 24-hour period. ${ }^{13,17,18}$ We agree with this finding, the risk of contamination with high pathogenic organisms from an endogenous source in the donor having an odds ratio of 1.0 $(p=0.86)$. We did not notice an effect of overgrowth of micro-organisms on the skin of the donor after a prolonged time. By contrast, an increased time between death and procurement reduced the risk of contamination with low pathogenic skin contaminants by a factor of 0.93 per hour. This occurred in the allografts with and without preceding organ procurement. We cannot explain this phenomenon but do not consider it to be of practical importance.

Rinsing with solutions of antibiotics is commonplace procedure. In an experimental model ${ }^{20}$ the microbial load was reduced by a factor of two. Our data showed that after rinsing with an antibiotic solution the risk of contamination with organisms of low pathogenicity was reduced. This effect was caused by a decrease in a number of allografts contaminated with a low microbial load, but there was no decrease in allografts with a high microbial load. The risk of contamination with organisms of high pathogenicity was not affected. We support the view ${ }^{2}$ that pathogenic organisms persist despite washing in antibiotic solutions. We found no clear advantage in rinsing allografts with the antibiotic solution, possibly because the exposure time was too short for the antibiotics to be effective.

The demand for bone and cartilage allografts is increasing and tissue banks must meet this demand. Tissue procurement must be performed under conditions that minimise the risk of bacterial contamination. Our study has shown that contamination with low pathogenic skin commensals is frequent and the rate can be influenced by the procurement team. Organisms shed from the staff and transferred directly to the graft before reaching the floor 
and other surfaces are a much greater cause of contamination than resuspended organisms. The exclusion of donors with severe trauma in highly colonised areas should diminish the risk of implanting a fresh frozen graft contaminated with organisms of high pathogenicity. A swab used to culture tissue is a method with low sensitivity. ${ }^{21}$ We believe that constant stringent monitoring of the level of contamination is necessary to identify and eliminate predisposing factors for contamination.

The authors would like to thank J. de Raadt for performing the many cultures.

No benefits in any form have been received or will be received from commercial party related directly or indirectly to the subject of this article.

\section{REFERENCES}

1. Tomford WW, Doppelt SH, Mankin HJ, Friedlaender GE. 1983 bone bank procedures. Clin Orthop 1983;174:15-21.

2. Malinin TI, Martinez OV, Brown MD. Banking of massive osteoarticular and intercalary bone allografts: 12 years' experience. Clin Orthop 1985;197:44-57.

3. Tomford WW, Thongphasuk J, Mankin HJ, Ferraro MJ. Frozen musculoskeletal allografts: a study of the clinical incidence and causes of infection associated with their use. J Bone Joint Surg [Am] 1990;72-A:1137-43.

4. Ivory JP, Thomas IH. Audit of a bone bank. J Bone Joint Surg [Br] 1993;75-B:355-7.

5. Bettin D, Dethloff M, Steinbeck J, Polster J. Organization of a bone and tissue bank. Z Orthop Ihre Grengeb 1994;132:453-8.

6. Munting E, Wilmart JF, Wijne A, et al. Effect of sterilization on osteoinduction: comparison of five methods in demineralized rat bone. Acta Orthop Scand 1988;59(1):34-8.

7. Pelker RR, Friedlaender GE. Biomechanical considerations in osteochondral grafts. In: Friedlaender GE, Goldberg VM, eds. Bone and cartilage allografts: biology and clinical applications. Park Ridge: AAOS, 1989:155-62.
8. Hamer AJ, Strachan JR, Black MM. Biomechanical properties of cortical allograft bone using a new method of bone strength measurement: a comparison of fresh, fresh-frozen and irradiated bone. $J$ Bone Joint Surg [Br] 1996;78-B:363-8.

9. AATB. Standards for tissue banking. Virginia: AABT, McLean, 1989

10. EAMT. Standards for tissue banking. EAMST 1992.

11. Tomford WW. Musculoskeletal tissue banking. New York: LippincottRaven, 1993.

12. Cerc and Cytel EGRET version 0.26.6; Statistic and Epidemiology Research Corporation (SERC) Seattle, Washington.

13. Martinez OV, Malinin TI, Valla PH, Flores A. Postmortem bacteriology of cadaver tissue donors: an evaluation of blood cultures as an index of tissue sterility. Diagn Microbiol Infect Dis 1985;3:193-200.

14. Lidwell OM, Richards IDG, Polakoff S. Comparison of three ventilating systems in an operating room. J Hyg 1967;65:193-205.

15. Lidwell OM, Lowbury EJL, Whyte W, et al. Airborne contamination of wounds in joint replacement operations: the relationship to sepsis rates. J Hosp Infect 1983;4:111-31.

16. Whyte W, Hodgson R, Tinkler J. The importance of airborne bacterial contamination of wounds. J Hosp Infect 1982;3:123-35.

17. Ayliffe GAJ, Collins BJ, Lowbury EJL, Babb JR, Lilly HA. Ward floors and other surfaces as reservoirs of hospital infection. $J$ Hyg $1967 ; 65: 515-36$.

18. Dolan CT, Brown AL, Ritts RE. Microbiological examination of postmortem tissues. Arch Pathol 1971;92:206-11.

19. Koneman EW, Davis MA. Postmortem bacteriology: III clinical significance of microorganisms recovered at autopsy. Am J Clin Pathol 1974;61:28-40.

20. Veen MR. Bone allografts: a study into bacterial contamination, sensitivity of cultures, decontamination, and contribution to postoperative infection (Thesis). Leiden, The Netherlands, University of Leiden, 1994:128.

21. Veen MR, Bloem RM, Petit PLC. Sensitivity and negative predictive value of swab cultures in musculoskeletal allograft procurement. Clin Orthop 1994;300:259-63. 